\title{
Mexico: what is the impact of monetary policy on unemployment rates?
}

\author{
Alejandro Islas C. and Willy Walter Cortez
}

ABSTRACT

In this paper we analyse the effects of a monetary policy shock on Mexican unemployment rates. Unlike previous studies, this one re-estimates unemployment to produce alternative rates comparable to those of the Organization for Economic Cooperation and Development (oecd) member countries. We find that in response to tightening monetary policy, unemployment increases with a characteristic hump-shaped pattern also found in other studies. Our results are robust to different assumptions about the nature of Mexico's labour market. Institute of Mexico (ITAM). aislas@itam.mx

Willy Walter Cortez is Associate Professor at the Department of Quantitative Methods of the University of Guadalajara. He is a visiting fellow at the Ibero-American Institute for Economic Research at the University of Göttingen, Germany. wcortez@cucea.udg.mx 


\section{I}

\section{Introduction}

Since the late 1950s and early 1960s, inflation has become one of the major concerns in both industrialized and emerging economies. Friedman (1976) illustrated the negative impact of both high inflation and inflation volatility on economic performance. High inflation, for example, could reduce political cohesiveness since it overruns institutional arrangements and financial contracts based on a "normal" long-term price level. Higher price volatility, by increasing uncertainty, could lower economic efficiency and render market prices a less efficient system for coordinating economic activity. Because of all these negative effects on economic growth, central banks often consider inflation to be the greatest problem a country faces.

For Mexico, the empirical evidence concerning the negative impact of inflation on growth is somewhat mixed. For example, a recent study by Grier and Grier (2006) found that inflation uncertainty had had a negative and significant effect on Mexico's output; moreover, higher average inflation rates had induced higher inflation uncertainty, further affecting growth. However, Risso and Sánchez (2009) argue that inflation has had a positive impact on growth as long as it has been below the threshold level of 9\%. Inflation rates higher than this threshold have had a negative effect on growth.

By any reckoning, Mexico's monetary policy over the past 25 years has been successful in achieving price stability: inflation declined from a monthly average rate of $4.3 \%$ during the 1980 s to $0.4 \%$ during the early years of the twenty-first century. Mexico's monetary authorities have used different monetary instruments to pursue price stability, ranging from exchange-rate controls to base money control to inflation targeting. To achieve its inflation targets, Banco de México ${ }^{1}$ has maintained a policy of controlling the amount of money available to commercial banks via the balances they hold with it, resulting in changes to domestic interest rates. Higher interest rates, for example, have resulted in contractions of aggregate demand that have lowered domestic inflation. Furthermore, in an open economy with high capital mobility and flexible exchange rates, higher domestic interest rates further lower the inflation rate via appreciation of the domestic currency: an

${ }^{1}$ Banco de México is Mexico's central bank. appreciated domestic currency not only restrains exports, but also lowers the domestic prices of imported goods and increases the prices of exportable goods.

Empirical studies of the neutrality of monetary policy in Mexico present conflicting evidence. For example, Mendoza (2003) found that Mexico did not have a long-run volatility trade-off between output and inflation, so that monetary policy affected only prices in the long run. Galindo and Ros (2005), on the other hand, found that monetary policy had had some impact on the real sector.

Even though the negative impact of Mexico's tight monetary policy on aggregate demand has been recognized, ${ }^{2}$ a thorough discussion of how this policy has affected the labour market has yet to take place. This is a major shortcoming of the current research agenda in Mexico because it means that the cost of achieving price stability in terms of workers' welfare is overlooked. Even if we recognize that price stability is a necessary condition for economic growth in the long run, we should not overlook the short- and medium-run costs for workers' well-being.

We further explore the question of how responsive unemployment is to monetary policy in Mexico, a country that began its successful price stabilization programme during the second half of the 1980s. A related question is how permanent the impact of monetary policy on the unemployment rate is.

The model used to carry out the empirical analysis rests on the assumption that money is non-neutral; that is, we contend that changes in unemployment rates can be partly explained by monetary policy implemented to control inflation. Our central argument is that by affecting aggregate demand and thus output, monetary policy has some impact on unemployment rates. Our analysis involves the estimation of a structural vector autoregression model (SVAR). Variance decomposition shows which shocks have caused movements in the variables during the sample period, while the impulse response functions contain information about the magnitude and duration of the effect of a specific structural shock.

Another distinguishing feature of our analysis is that we consider both the official unemployment rate

\footnotetext{
2 See, for instance, Díaz de Leon and Greenham (2000)
} 
and an alternative one based on the definition used by the Current Population Survey (CPS) of the United States Bureau of Labor Statistics. We use the latter as a response to some criticisms made of the official unemployment rate.

Our results indicate that when the alternative unemployment rate is used, tightening monetary policy causes unemployment to increase with a characteristic hump-shaped pattern found in Alexius and Holmlund (2007) and Ravn and Simonelli (2008). The unemployment rate peaks after the second quarter at a level 0.26 points above its original level, and then slowly reverts back to that original level. Error variance decomposition results indicate that the monetary policy shock accounts for $3 \%$ to $27 \%$ of the fluctuation in unemployment. When we use the official unemployment rate, however, monetary policy shocks do not have much impact.

The paper is organized as follows. Section II presents a brief discussion of the non-neutrality of money and describes how monetary policy can affect unemployment. Section III reviews the monetary policies followed by the Mexican authorities during the period of analysis, while section IV presents some key characteristics of the Mexican labour market and introduces an alternative indicator of unemployment rates. Section V discusses the methodology used to carry out the empirical analysis, section VI presents the main empirical results, and section VII concludes.

\section{II}

\section{Is money neutral?}

Discussions about money neutrality can be traced back to Cantillon's essay of 1775 . His argument was that, under the gold standard, increases in the money supply would encourage higher spending, which in turn would stimulate production. This positive effect on production would be short-lived, however, for higher demand would also induce higher prices which, in turn, would have a negative impact on production. We find the same argument in Hume's (1985) paper on money. His views were restated by Newcomb (1885) and Fisher (1911) and became what is now known as the quantity theory of money.

The non-neutrality of money, on the other hand, is a key feature in Keynesian economics. Keynes's view about the impact of money on real variables is found in his General Theory of Employment, Interest and Money. Central to his argument is the role played by domestic interest rates in inducing changes to aggregate demand. In the Keynesian framework, the rate of interest is the reward for parting with liquidity. To the extent that the interest rate affects the marginal efficiency of capital, which in turn determines investment, changes in the quantity of money will affect output and employment. The overall impact on aggregate demand is further strengthened by the responsiveness of consumption to changes in investment. In Keynes's view, the interest rate depends partly on the state of liquidity preferences and partly on the quantity of money, so that changes in the quantity of money will induce changes in the interest rate, ceteris paribus. Chick (1983), in turn, argues that interest rates will be affected by open market operations or by variations in banks' reserves or reserve requirements designed to affect liquidity or the supply of credit, or both.

Given the capacity of interest rates to affect output and thus unemployment, the monetary authority can use monetary policy to induce changes in the domestic interest rate in order to achieve certain specific goals. If, for instance, inflation is assumed to be caused by excess demand, then higher interest rates can be used to control inflation via the contraction of aggregate demand. Moreover, in an open economy with high capital mobility, higher interest rates will induce appreciation of the domestic currency, which will not only restrain price increases but also further reduce aggregate demand.

Taylor (1994), on the other hand, has suggested that the monetary authority's efforts to keep prices stable may also cause production to fluctuate more, while attempts to smooth the production cycle may induce higher price volatility. To reduce price volatility, monetary policy would have to be biased even more towards restraining aggregate demand.

In general, there is a consensus about the nonneutrality of money in the short run. Recently, however, there has been a growing debate about the long-run impact of monetary policy on the real sector. Blanchard (2003), for instance, contends that money is non-neutral and that monetary policy can have large and long-lasting 
effects on real interest rates and, by implication, on unemployment. There are three possible channels of transmission for this. One could be the effect of the real interest rate on current unemployment. The longer a spell of unemployment is, the likelier the unemployed are to lose their skills. Therefore, sustained high unemployment will lead to an increase in the natural rate itself. A second possible channel is capital accumulation: the real interest rate affects the cost of capital, the cost of capital affects capital accumulation and capital accumulation affects the demand for labour and thus unemployment. Therefore, a sustained increase in real interest rates leads first to an increase in the actual unemployment rate and later, as capital accumulation decreases, to an increase in the natural rate. The third potential mechanism might be the effect of the real interest rate on a firm's mark-up. To the extent that this had a direct impact on employment, unemployment would be affected by monetary policy through this mechanism. ${ }^{3}$

The theory of long-run neutrality of money predicts that tight monetary policy will not affect the growth path; yet Schettkat and Sun (2008) illustrate that in Europe, for example, monetary policy has been asymmetrical because of central banks' fear of inflation. They present evidence that this asymmetry has lowered long-run trend growth

\footnotetext{
3 There is a fourth potential mechanism which falls within the real business cycle approach: the labour supply depends on interest rates. This is an area that has not yet been investigated for less developed economies.
}

in some European economies. ${ }^{4}$ This result is borne out by other studies that have also found evidence against long-run money neutrality.

To some extent, this asymmetry of monetary policy is an intrinsic feature of inflation targeting. Studies of the impact of asymmetric monetary policy on output in less developed economies are uncommon. One of the few that do exist is Galindo and Ros (2005). They argue that monetary policy in Mexico has been biased towards exchange-rate appreciation since inflation targeting began, i.e. the central bank has responded only when the exchange rate has been undervalued, not when the real exchange rate has been overvalued. Furthermore, the negative impact of real exchange-rate appreciation on output means that monetary policy (or inflation targeting) has restrained economic growth in Mexico.

A conclusion we can draw from this review is that there are strong theoretical arguments for expecting not only short-run non-neutrality but long-run non-neutrality as well. The question then becomes whether monetary policy has had a short- and long-term impact on Mexican unemployment. In the next section we briefly describe the monetary and fiscal policies implemented in Mexico during the period from 1987 to 2004.

\footnotetext{
${ }^{4}$ Schettkat and Sun (2008) give the following account. An external negative shock pushes the economy into a recession which is not fully counteracted by monetary policy. During the upswing, fearing inflation, the central bank does not fully accommodate the recovery. As a result, the economy will not swing back to its original growth path but will remain below it.
} 


\section{III}

\section{Monetary and fiscal policies in Mexico}

Our analysis begins in 1987, in the midst of a period characterized by high macroeconomic instability. During that time, Mexico's monetary policy had the twin objective of promoting economic growth with price stability (Garriga, 2010). A distinguishing feature of this monetary policy was that it attempted to control inflation through exchange-rate stability. Messmacher and Werner (2002) argue that the Mexican authorities used multiple instruments to control inflation, with fiscal instruments being prominent alongside exchange controls. In addition, the government introduced a temporary wage freeze and price controls as part of an Economic Solidarity Pact.

The use of these instruments is explained by the assumption that inflation was mainly caused by fiscal deficits which pushed aggregate demand above aggregate supply. In this context, excess demand was seen not only as inducing higher domestic prices but also as leading to current account deficits. External deficits, in turn, would create pressure for devaluation of the exchange rate, which could further exacerbate inflation (Garriga, 2010).

As most of the price and wage controls were gradually lifted, the anti-inflation programme evolved into a more orthodox strategy in which fiscal adjustment and an exchange-rate anchor became the main policy elements. Between 1988 and 1994, the Mexican authorities made several modifications to the exchange-rate system, with the dual and fixed system being replaced by a pre-announced rate of devaluation (where the rate of devaluation was set below the rate of inflation). In November 1991, Mexico's central bank implemented a narrow exchange-rate band with a sliding ceiling (Messmacher and Werner, 2002). Between 1992 and October 1993, the nominal exchange rate was remarkably stable. In December 1993, Mexico's Congress granted the central bank operational autonomy and established that its only objective was to preserve the stability of the purchasing power of money. This replaced the twin objectives it had had until then.

Throughout most of this period, Mexico's managed exchange-rate regime was supported by prudent fiscal policy. Indeed, the country moved from a fiscal deficit of $12.5 \%$ of gross domestic product (GDP) in 1988 to a fiscal surplus in 1992 (Garriga, 2010). After 18 months, this combination of policies yielded the expected results: inflation fell drastically to less than $20 \%$ annually. From then on, though, the pace of disinflation became sluggish.
Sánchez (2005) maintains that between 1988 and 1994, the amount of credit going to the private sector grew significantly, at annual rates of about $30 \%$. The absence of an adequate supervisory and regulatory framework, compounded by poor accounting standards and insufficient recognition of past loans falling due, among other things, meant that this lending explosion negatively affected the profitability of the banking system. Combined with a lack of consistency between monetary and exchange-rate policies, the problems of the banking system precipitated a very serious crisis at the end of 1994.

In December 1994, faced with a serious balanceof-payments and financial crisis, the central bank was no longer able to defend the predetermined United States dollar-peso parity and so allowed the peso to float. The peso immediately depreciated and domestic prices increased steadily, rising at a monthly rate of $3.6 \%$ throughout 1995 . The interbank interest rate increased from 17\% in the third week of August 1994 to $110 \%$ in the third week of March 1995, which induced a severe slump in the real economy. Output and employment suffered considerably: output fell by $6.2 \%$, while open unemployment was up to $7.6 \%$ by mid-1995. Sánchez (2005) states that the recession and unemployment caused by the financial crisis were the worst since the Great Depression.

The new strategy achieved price stability indirectly, since it sought to modify agents' expectations as well as interest rates and the exchange rate. Because these elements affect aggregate demand, the central bank was able to determine the future behaviour of inflation (Díaz de León and Greenham, 2000). To induce changes in domestic interest rates, the central bank decreed changes in the cumulative monthly balance held with it by commercial banks (the corto) ${ }^{5}$ In the monetary authorities' view, inflation was a problem caused by excess demand. ${ }^{6}$ Therefore, unexpected increases in

\footnotetext{
${ }^{5}$ On 21 January 2008 the central bank adopted the overnight interbank rate as its operating target, replacing the measure used hitherto, which was the balance in commercial banks' current accounts held with the central bank

6 Garriga (2010) goes further and argues that the new monetary authorities did not believe in the existence of a trade-off between unemployment and inflation.
} 
actual inflation or inflation expectations were dealt with by reducing the corto, thereby inducing commercial banks to bid up interest rates.

The evolution of monetary policy since the adoption of the floating exchange-rate regime has included the following main elements. First, adoption of quantitative objectives based on aggregates such as the monetary base, predominant during 1995-1997. Second, in early 1998 the central bank announced a change in its strategy: it began targeting inflation. In particular, the 1999 monetary programme set an annual inflation goal of no more than $13 \%$ for the National Consumer Price Index and proposed, as a commitment for the next five years, a gradual convergence with the inflation rate of the country's main trading partners. In 2001, the goal of monetary policy was to stabilize the National Consumer Price Index at 3\%. However, in mid-2002 the central bank announced that this commitment would have a margin of tolerance of \pm 1 percentage point.

Castellanos (2000) also shows that changes in the corto have had a strong impact on the entire interest rate structure and argues that the impact is strongest for short-term interest rates. The magnitude of this effect has changed over time, and since June 1998 it has been more unstable. In point of fact, Gaytán and González (2006) found that there had been a change in the transmission mechanisms of monetary policy as a result of inflation targeting. They argued that exchange-rate fluctuations were having a smaller effect on price formation, the formation of inflation expectations and nominal interest rates, while changes in nominal interest rates had been more effective in influencing the real exchange rate and inflation.

To summarize, in this section we have described the monetary policy used by Mexico's central bank to control inflation. The instruments used have varied over time. During the early years, exchange-rate and price controls were used intensively. Then a fixed exchange rate was replaced by a floating rate to give the central bank the freedom to control monetary aggregates and interest rates, or both. During this second stage, interest rates were the predominant instrument used to control inflation. To the extent that both interest rates and exchange rates affect output and thus employment, we contend that monetary policy has the potential to have a significant impact on unemployment.

\section{IV}

\section{The Mexican labour market}

The purpose of this section is twofold. First, we describe key characteristics of Mexico's labour market with a view to providing a better understanding of employment dynamics and the way unemployment might respond to policy shocks. Second, in the light of some criticisms made of the official unemployment rate, we estimate an alternative unemployment rate and use it to assess the impact of monetary policy.

\section{The nature of the Mexican labour market}

There are two contrasting views of the nature of the Mexican labour market. On the one hand, there is the idea that it is heavily regulated by laws that impede job creation (Heckman and Pagés, 2001; Gill and others, 2001). In this view, output growth does not translate into employment growth but rather into real wage changes. It is argued that job security provisions (which include severance payments) increase dismissal costs for firms. These costs discourage firms from dismissing workers whenever there is a negative shock and reduce job creation in upturns. Heckman and Pagés (2001) found that Mexico exhibited one of the highest indices of job security in Latin America, which implies that it has one of the most regulated markets in the region.

Employment rigidity can also be increased by the existence of labour unions. Maloney (2009), for example, argues that Mexican unions value employment over wages, so that output fluctuations affect wage rates more than employment. This can be explained by several factors. First, Mexico has no unemployment insurance; hence, workers value employment stability more than wages. Second, since the early twentieth century the major unions have had a close and long-standing relationship with the government and have cooperated in implementing policies to reduce inflationary pressures. In particular, since the late 1980s unions have settled, on average, for nominal wage growth below inflation. Third, job growth was slow relative to population growth during the late 1980s and early 1990s. These elements explain 
why output fluctuations are correlated more with real wage fluctuations than with employment changes. They might also explain Alcaraz's conclusion that real wages do not depend on unemployment in the formal sector (Alcaraz, 2009).

On the other side of the debate, there is the argument that even though Mexico's labour market is heavily regulated by employment laws, in practice compliance with such laws is very limited. Moreover, a number of schemes introduced since the late 1980s have increased employment flexibility (Marshall, 2004). Among these schemes we find the increased use of short-term contracts to avoid the inflexibility of permanent employment. This is particularly true of the maquila and service sectors, the fastest-growing sectors in the Mexican economy since the late 1980 s.

Furthermore, Alcaraz and others (2008) contend that the employment share of the service sector has increased at the expense of Mexico's manufacturing employment since 2000. According to these authors, this recomposition of employment has entailed not only an increase in the service sector's employment share but an expansion of the informal sector as well. The upward trend of employment in the informal sector has occurred despite the wage differential between formal and informal employment. They also find evidence that the rate of transition between formal and informal employment is higher than that between manufacturing and service sectors. They point out that higher mobility between the formal and informal sectors (and vice versa) would indicate the existence of institutional labour market rigidities in Mexico's formal sector.

The existence of a large informal sector ${ }^{7}$ somewhat offsets the employment rigidities caused by labour regulations in the formal sector. The question is whether or not this offsetting force is strong enough for us to be able to characterize the Mexican labour market as being fairly flexible.

In short, two types of factors coexist within Mexico's labour market. On the one hand, there are some labour market institutions that increase employment rigidity while also increasing real wage flexibility; namely, labour regulation and unions. On the other hand, we find elements that offset the negative effect of these on employment flexibility, including weak enforcement of labour regulations and the existence of the informal sector. A priori, we do not know which of these two types of factors has a stronger effect on employment flexibility.

7 Alcaraz (2009) argues that the informal sector may represent as much $40 \%$ of the Mexican labour force.

\section{How accurate are Mexico's unemployment figures?}

To an outsider, Mexico's low official unemployment rates represent a puzzle. How could a country with such low rates of unemployment grow so little? At about $3.5 \%$, Mexico's unemployment rate over the last 20 years or so has been on average one of the lowest among the members of the Organisation for Economic Cooperation and Development (OECD), with only Luxembourg and the Republic of Korea presenting lower rates. ${ }^{8}$ Yet its average annual rate of per capita GDP growth has been $1.2 \%$, far lower than the $5.8 \%$ reported by the Republic of Korea, which has similar unemployment rates. 9

Several authors have argued that Mexico's low official unemployment rates can be explained by a combination of several elements, namely: (i) the lack of unemployment benefits, (ii) the existence of a large, fairly well-remunerated informal sector, (iii) high rates of labour migration to the United States, and (iv) the exclusion of rural areas when unemployment rates are estimated, as unemployment is higher there than in urban areas.

Our contention, however, is that although some of these factors might partially account for the low rates of unemployment in Mexico, a more significant explanation can be sought in some methodological issues relating to the estimation of unemployment rates. Fleck and Sorentino (1994) and Martin (2000), for example, argue that if the concepts and methodology used by the United States Bureau of Labor Statistics are followed, Mexican unemployment rates increase by between $40 \%$ and $70 \%$. Revenga and Riboud (1993) reach the same conclusion, although for a different reason: the official statistics do not take into account the temporarily unemployed, or those who are unemployed but not included in the surveys. ${ }^{10}$

To tackle one of the main criticisms of the official statistics, we re-estimated Mexico's unemployment rate using the quarterly National Survey of Urban Employment (ENEU) and following the CPS criteria. First, we considered

\footnotetext{
8 OECD members averaged a rate of $5.93 \%$ between 1987 and 2004 (http://stats.oecd.org).

9 Between 1987 and 2004, Mexico's total real GDP grew at an annual average rate of $3.01 \%$, while its population grew by an average of $1.8 \%$ a year. The Republic of Korea, on the other hand, grew at an annual rate of $6.2 \%$, while its population growth was $0.33 \%$ during the same period (output data are from the OECD website http://stats.oecd. org, while data on population growth come from World Population Prospects: The 2006 revision, United Nations, 2007, table A.8).

10 This is particularly relevant when a person is unemployed and not seeking work at the time of one survey but then finds a job before the next survey is carried out and thus features as employed.
} 
only workers between the ages of 16 and $75 .{ }^{11}$ Second, to obtain the overall unemployment rate, we used only the original 16 cities included in the ENEU. Third, we did not treat as employed those who were on strike or laid off because of shortages of working capital or raw materials or a lack of repairs. We also excluded people working without pay for up to 15 hours a week. That is, they were not categorized as part of the economically active population (EAP) or as employed. The resulting series allows Mexico's unemployment rates to be compared directly to those of the OECD countries.

The evolution of official and alternative unemployment rates is displayed in figure 1. Compared to the official rates, the alternative measure is about $100 \%$ higher, i.e. the average rate of unemployment for the 1987-

11 Prior to 2005, Mexican statistics covered people working from the age of 12 . In response to criticisms, the lower age limit was raised to 14 in 2005 .
2004 period goes up from $3.4 \%$ to $6.4 \%$. The overall behaviour of the two series, however, is fairly similar. The main difference is seen during the period prior to the 1995 crisis. In the early 1990s, both series show a slight upward trend which peaks by the end of 1995 . The unemployment rate begins to decline rapidly in 1996 , bottoming out by the end of 2000 in both series. This improvement is short-lived, however, for in the next year unemployment begins to trend upward again. Both unemployment series exhibit large cyclical fluctuations as well as short-run variations.

In the previous section we described the main monetary and fiscal policies followed in 1987-2003. We argued that the main objective of both sets of policies was to control inflation. To do this, however, the central bank needed to restrain aggregate demand, which in turn resulted in a contraction of output and thus in an expansion of unemployment. The econometric technique used in this analysis is presented below.

FIGURE 1

Mexico: official and alternative unemployment rates

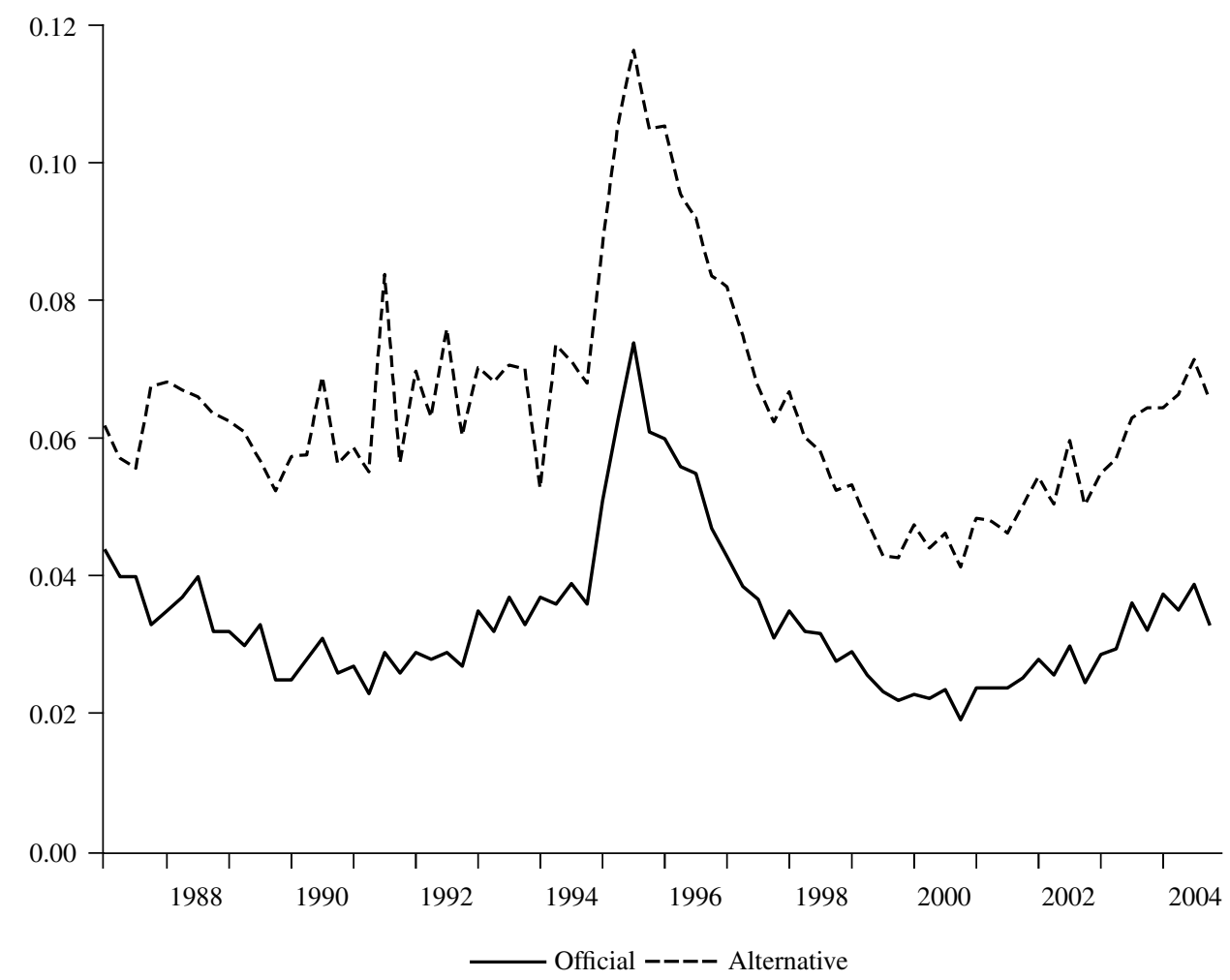

Source: National Institute of Statistics and Geography (INEGI), National Survey of Urban Employment (ENEU), various years. 


\section{V}

\section{Methodology}

We use a structural vector autoregression model (SVAR) to analyse the dynamic impact of monetary policy on unemployment. It should be noted that another way to perform the analysis is through the use of a Markovswitching vector autoregression model. Given the small sample size of our data set, however, the degrees of freedom would have been quickly eroded, which is why we did not carry out an analysis of that type. Our analysis is complemented by estimation of the impulse response function and variance decomposition.

Thus,

$$
A X_{t}=B(L) X_{t-1}+\varepsilon_{t}
$$

where $X_{t}$ is an $(n x l)$ vector of endogenous variables; $A$ is an (nxn) matrix of coefficients describing the contemporaneous correlation among the variables; $B(L)$ is an (nxn) matrix of polynomials in the lag operator, $L$; and $\varepsilon_{t}$ is an $(n x l)$ vector of structural shocks. Thus, each of the system's variables can be influenced by its own idiosyncratic shocks and by shocks from the other variables. The matrices $A$ and $B(L)$ determine how shocks to each variable are transmitted through the system, both contemporaneously and in subsequent periods. The reduced form of the SVAR can be expressed by:

$$
X_{t}=A^{-1} B(L) X_{t-1}+A^{-1} \varepsilon_{t}=C(L) X_{t-1}+e_{t}
$$

where $e_{t}=A^{-1} \varepsilon_{t}$ describes the relationship between the model's reduced and structural shocks. In fact, the model's reduced shocks are linear combinations of the pure structural shocks.

A necessary condition for establishing the relationships between the reduced and structural shocks is that the system be identified. As is well known, to identify the structural model from an estimated VAR, it is necessary to impose $\left(n^{2}-n\right) / 2$ restrictions on the structural model.

Several different methods of identification are available in the literature on sVARs. Blanchard and Diamond (1989) use a priori assumptions about the signs of structural parameters to identify the range of values of matrix $A$ that are consistent with the data. Shapiro and Watson (1988) and Blanchard and Quah (1989) use assumptions about long-run multipliers to achieve identification. Blanchard and Quah (1989) start with orthogonal shocks. In a two-variable model, one is assumed to represent a supply shock and the other a demand shock. For example, productivity shocks are separated from demand shocks by assuming that demand shocks do not affect real output in the long run while productivity shocks do. On the other hand, Sims (1980) argues that identification is achieved using short-run restrictions on the timing of the effects of shocks only, i.e. monetary policy shocks are frequently identified by assuming that changes in the interest rate do not affect inflation in the same period because prices are sticky and respond with a delay. In our analysis, we follow Sims' (1980) approach to identify our model.

\section{Definition of variables and data}

Our SVAR includes the following variables: unemployment rates, the output gap (since demand for labour is a derived demand that depends on the fluctuations of output), and an indicator of monetary policy. We also include three variables that are thought to affect Mexican unemployment: United States output, an indicator of fiscal policy, and labour productivity. The inclusion of these variables in our analysis is justified below.

Our sample period covers both fixed and floating exchange-rate regimes. Under a fixed exchange-rate system, central banks lose the freedom to determine their monetary policy, while with floating exchange rates they gain control over monetary policy and can use it to attain their specific goals. With a floating exchange rate, moreover, interest rates and the exchange rate become interdependent on each other. The effects they have on output and thus unemployment operate through different mechanisms. Instead of using exchange rates and interest rates independently as instruments for measuring monetary policy, we use a composite index of monetary policy. Specifically, we use the Monetary Conditions Index (MCI), which captures the total effect (direct and indirect) of the exchange rate and the interest rate on domestic output.

The MCI is typically measured as the weighted sum of changes in the short-term interest rate and exchange rate relative to a base period, with the weights being generally derived from empirical econometric models reflecting the estimated impact of these variables on 
output or inflation. ${ }^{12}$ Thus, the MCI determines the extent of tightening or loosening of monetary conditions in an economy by capturing deviations in these two variables from the base period. Accordingly, lower interest rates drive looser or more expansionary monetary conditions and higher rates denote tighter conditions, which may also be achieved through domestic currency appreciation or a combination of both measures.

In our work, we use the MCI as an indicator of policy stance. For instance, the MCI calculated relative to a base period indicates whether policy has become tighter or looser relative to that base period. In this construct, the absolute value of the MCI does not provide the basis for any meaningful interpretation; rather it is the direction of movement which reveals the change in policy stance. Using the estimated coefficients of the interest-rate and exchange-rate variables in the cointegration vector of the aggregated output system, the ratio or weight of the MCI index turns out to be 1:4.2, which indicates that the exchange rate has a larger impact on aggregate output than interest rate effects. ${ }^{13}$

We define the output gap as the difference between observed output and potential output, and we assume that potential output is best characterized as being driven by a stochastic process and can be obtained using the Hodrick-Prescott filter. ${ }^{14}$ Thus, the domestic output gap is $\tilde{y}=\left(y-y^{*}\right)$, where $y^{*}$ is the permanent component of output, $y$ being observed real GDP.

Insofar as Mexico's stabilization programme included the reduction of fiscal deficits, we need to control

\footnotetext{
12 We derived the relative weights of the interest rate and exchange rate for the MCI from an aggregate demand equation. The literature has suggested three approaches to estimating relative weights: (i) the single equation approach, involving estimation of either an output or a price equation; (ii) the trade share approach, involving estimation of an equation for the ratio of long-run exports to GDP; (iii) the multiple equation approach, involving estimation of the system of equations through cointegration. We used vector autoregressive (VAR) and Johansen cointegration models to avoid omitted variable bias, dynamic exogeneity and feedback problems. The cointegration approach takes care of these problems.

${ }^{13}$ Recent empirical studies have shown that there has been a change in the transmission mechanism of monetary policy since 2001 as a consequence of the new anti-inflation strategy based on inflation targeting. Gaytán and González (2006) argue that output and inflation have become more sensitive to interest rates, whereas the real exchange rate has become less important. Our results differ somewhat because our period of analysis goes back to 1987, when the exchange rate was the nominal anchor. In fact, the nominal exchange rate was the predominant instrument until 1994.

${ }^{14}$ Choosing a large $\lambda$ in the Hodrick-Prescott filter implies the view that supply shocks are deterministic and that variations in output come almost entirely from demand shocks. Choosing a very small $\lambda$ implies the view that most variations in output are also variations in potential or trend output and hence are driven by supply shocks.
}

for the impact of fiscal policy on unemployment. We therefore introduced the structural primary surplus into our model. The structural primary surplus is calculated as the difference between the observed deficit and the cyclical deficit. The structural deficit, in other words, is the government deficit adjusted for business cycles measured as the ratio of potential output to actual output. Following Pastor and Villagómez (2007), we adjust the government deficit for business cycle fluctuations. ${ }^{15}$ This adjustment is made by multiplying tax revenues by the ratio of potential GDP to actual GDP, raised to the power of the elasticity of tax revenues to actual GDP. To construct the structural primary surplus, budgetary data obtained from the Ministry of Finance and Public Credit were used.

Several studies have shown the high degree to which Mexican business cycles are co-dependent upon those of the United States. This finding is self-evident, given that more than $90 \%$ of exports go to the United States economy. To control for the impact of this on unemployment in Mexico, we include the United States output gap, $\tilde{q}$, as the indicator of foreign demand in our model. Thus, $\tilde{q}=\left(q-q^{*}\right)$, where $q^{*}$ is potential United States output, estimated using the Hodrick-Prescott filter, and $q$ is observed United States output.

Finally, we also include a proxy for technical change. It has been argued that labour-saving technical change can affect unemployment rates, and to control for such changes in technical efficiency we introduce labour productivity into our model as an exogenous variable. Labour productivity is measured as output per employed worker.

We use available quarterly data from the first quarter of 1987 to the fourth quarter of 2004, giving a total of 74 observations. The Mexican output gap is estimated from real GDP, obtained from the National Institute of Statistics and Geography (INEGI), while the United States output gap is calculated from United States real GDP as obtained from the main OECD economic indicators. The indicator of Mexico's fiscal policy is the fiscal surplus, while the indicator of labour productivity is output per worker.

We use both the official and the alternative unemployment series, both of them seasonally adjusted using TRAMO-SEATS. By the same token, the Mexican and

\footnotetext{
15 According to Hayford (2005) the logic behind structural measures is that "One problem in identifying the effect of fiscal policy [...] is that government revenues and transfer payments respond to fluctuations in economic activity as well as potentially cause fluctuation in economic activity. One way to deal with this problem is to control for the effect of cyclical fluctuations by using cyclically adjusted or structural measures of fiscal policy."
} 
foreign output gaps were obtained using the HodrickPrescott filter with $\lambda=1600$, following seasonal adjustment using TRAMO-SEATS.

\section{Identification}

The SVAR model includes three endogenous variables: monetary policy $(m c i)$, the domestic output gap $(\tilde{y})$ and unemployment $(u)$, and three exogenous variables: the United States output gap $(\tilde{q})$, productivity $(p)$ and fiscal policy $(g)$. These last three variables were tested for exogeneity following Hyeon-Seung (2005). We found that $\chi^{2}(48)=37.007[0.87] .^{16}$

The order of matrix $A$ is as follows. Monetary policy is shown first, followed by excess domestic demand and then the unemployment rate. Monetary policy is identified by assuming that changes in the interest rate do not affect excess demand in the same period because prices are sticky and respond with a delay. This implies that $\alpha_{21}=0$. Given the existence of a large informal sector and the high degree of transition between formal and informal employment (see section IV, subsection 1), unemployment rates will not necessarily change as output changes. Output fluctuations will induce flows between the formal and informal sectors, so the unemployment rate will remain fairly rigid. This translates into

16 Values in parentheses refer to the degree of freedom and those in square brackets are the marginal significance levels of the test. $\alpha_{32}=0$. It is important to note that labour market rigidity is not posited on strict labour legislation preventing output fluctuations from affecting unemployment. Instead, rigidity is posited on the existence of a large informal sector and high labour mobility between the formal and informal sectors so that unemployment is not affected contemporaneously by output fluctuations. It is paradoxical that, in Mexico, labour rigidity results from the existence of a labour market that is very flexible indeed. ${ }^{17}$

The third restriction is derived from the fact that monetary policy does not depend on unemployment, i.e. $\alpha_{13}=0$.

17 Calderon-Madrid (2000), Alcaraz and others (2008) and Alcaraz (2009) present some evidence for the high degree of labour mobility between the formal and informal labour markets. The existence of a large informal labour market that is closely intertwined with the formal one means that output fluctuations do not necessarily translate into fluctuations in unemployment, or vice versa. In other words, the existence of a large informal labour market indicates that the relationship between the cyclical components of output and unemployment is not necessarily linear or contemporaneous. Instead, we might observe that a given change in output will induce higher labour mobility between the formal and informal sectors so that the unemployment rate remains constant. Consider, for example, that if employment is decomposed into its formal $\left(e_{f}\right)$ and informal $\left(e_{i}\right)$ components, then the following should be true: $u=1-e_{f}-e_{i}$. That is, variations in unemployment will ensue only if formal and informal employment move in the same direction, which in reality does not occur. Thus, the impact of output variations on unemployment will be fairly low unless the informal sector lacks the requisite flexibility. This holds true even in the face of the institutional rigidities mentioned by Heckman and Pagés (2001).

\section{VI}

\section{Empirical analysis}

In this section, we present the estimates of the parameters and carry out some complementary analyses such as impulse response analysis and analysis of variance. We also conduct tests to verify the robustness of our results.

\section{1. svar estimation}

Since the primary interest in the SVAR analysis is to determine the relationship between the variables and not the parameter estimates in themselves, we follow the recommendation of Sims (1980) and Sims, Stock and Watson (1990) against differencing even if the variables contain a unit root. Sims, Stock and Watson (1990) argue that transforming the model into a stationary form is in many cases unnecessary, for the real issue is whether the estimated coefficient or test statistics of interest have a distribution that is non-standard when in fact the regressors are integrated. However, we have added some deterministic components in a way that yields a stationary VAR.

Thus, given that both unemployment series (the official one and the alternative one) are non-stationary over the sample period, ${ }^{18}$ and since we want to determine the

18 See table A.2, which includes the unit root tests. We use the Lee and Strazicich (2003) minimum Lagrange multiplier unit root test with two structural breaks. 
persistence of monetary policy shocks rather than assume that the effects are permanent, we added a deterministic time trend to the model to yield a stationary SVAR and also a stationary unemployment rate. To the extent that monetary policy might be affected by expected inflation, we added this to the SVAR. We used lagged inflation as a proxy for expected inflation. While lagged inflation was statistically significant only in the MCI equation, including this variable did not have any qualitative effect on the rest of the results. The econometric results are shown in the appendix (see table A.1). Our analysis is therefore based on a parsimonious model without expected inflation.

Before estimating our SVAR model, we tested the identification restrictions $\left(\alpha_{21}=\alpha_{32}=\alpha_{13}=0\right.$.). The likelihood ratio test was 0.003 and was not significant when contrasted with critical values of the chi-square distribution with three degree of freedom; accordingly, the joint hypothesis could not be rejected. The optimal lag length was derived using the Akaike information criterion (AIC) and the Bayesian information criterion
(BIC), leading to a choice of two lags. When the official unemployment rate was used, the estimated SVAR coefficients were either statistically insignificant or had the wrong signs. In fact, the initial impact of a monetary shock was a reduction of the unemployment rate, a result that is clearly contrary to economic theory. ${ }^{19}$

Table 1 reports the SVAR coefficients estimated using the alternative unemployment series. As we can see, there are no signs of misspecification in any of the equations. Table 1 contains the sum of coefficients on the two lags of each variable and the Wald test for their joint significance; p-values are in parentheses. The results are as expected; a tight monetary policy increases unemployment and decreases domestic demand. Higher domestic demand decreases unemployment. A fiscal surplus decreases domestic demand, while the impact on

${ }^{19}$ In figure 3 we compare the results of the impulse response functions for the two unemployment rates (model 1 and model 5).

TABLE 1

svar estimates

( $p$-values in parentheses)

\begin{tabular}{|c|c|c|c|}
\hline & $\begin{array}{l}\text { Unemployment } \\
\operatorname{Ln}(u)\end{array}$ & $\begin{array}{l}\text { Domestic demand } \\
\left(y-y^{*}\right)\end{array}$ & $\begin{array}{l}\text { Monetary policy } \\
\text { (mci) }\end{array}$ \\
\hline $\operatorname{Ln}(u)$ & $\begin{array}{c}0.759 \\
(0.000)\end{array}$ & $\begin{array}{l}-0.351 \\
(0.081)\end{array}$ & $\begin{array}{c}0.516 \\
(0.398)\end{array}$ \\
\hline$\left(y-y^{*}\right)$ & $\begin{array}{l}-0.061 \\
(0.090)\end{array}$ & $\begin{array}{c}0.568 \\
(0.000)\end{array}$ & $\begin{array}{c}0.351 \\
(0.263)\end{array}$ \\
\hline$L(M C I)$ & $\begin{array}{c}0.024 \\
(0.064)\end{array}$ & $\begin{array}{l}-0.067 \\
(0.007)\end{array}$ & $\begin{array}{c}0.582 \\
(0.000)\end{array}$ \\
\hline $\begin{array}{l}\text { United States output } \\
\left(q-q^{*}\right)\end{array}$ & $\begin{array}{c}-0.183 \\
(0.014)\end{array}$ & $\begin{array}{c}0.293 \\
(0.036)\end{array}$ & $\begin{array}{l}0.315 \\
(0.457)\end{array}$ \\
\hline Productivity $(t)$ & $\begin{array}{l}-0.017 \\
(0.943)\end{array}$ & $\begin{array}{c}1.809 \\
(0.000)\end{array}$ & $\begin{array}{l}5.175 \\
(0.000)\end{array}$ \\
\hline Fiscal surplus $(g)$ & $\begin{array}{c}0.153 \\
(0.758)\end{array}$ & $\begin{array}{l}-2.711 \\
(0.005)\end{array}$ & $\begin{array}{l}-7.690 \\
(0.009)\end{array}$ \\
\hline Time trend & $\begin{array}{c}0.0008 \\
(0.884)\end{array}$ & $\begin{array}{l}-0.038 \\
(0.001)\end{array}$ & $\begin{array}{l}-0.011 \\
(0.744)\end{array}$ \\
\hline Dummy95 & $\begin{array}{c}1.766 \\
(0.012)\end{array}$ & $\begin{array}{c}-3.138 \\
(0.018)\end{array}$ & $\begin{array}{l}35.167 \\
(0.000)\end{array}$ \\
\hline Adjusted $\left(R^{2}\right)$ & 0.834 & 0.811 & 0.837 \\
\hline
\end{tabular}

Log likelihood -339.93

Portmanteau (12) 105.1633 (0.1311)

Source: authors' estimates.

Note: The table contains the sum of the coefficients on the two lags of each variable. Wald test for joint significance of both lags of each variable. The portmanteau joint test for white noise residuals is shown.

mci: Monetary Conditions Index. 
unemployment has the right sign but is not significant. United States output shocks decrease unemployment and increase domestic demand, while productivity shocks increase domestic demand.

\section{Impulse response functions}

Since we are particularly interested in the effects of monetary policy shocks on the unemployment rate, figure 2.A shows the dynamic response of unemployment to an exogenous tightening of monetary policy, along with its percentile bands. The results show that unemployment responds positively to positive monetary policy shocks, indicating that an exogenous monetary policy tightening of $1 \%$ induces an increase of 0.26 percentage points in unemployment after two quarters. After five years, unemployment is still 0.06 percentage points higher than it would have been without the shock. As this is a stationary VAR, all shocks are temporary but monetary policy itself is persistent, so the shock dies away only gradually. In response to the tight monetary policy, unemployment increases with a characteristic humpshaped pattern like the one found by other studies. ${ }^{20} \mathrm{It}$ peaks after three quarters before slowly reverting back to its original level.

20 See, for example, Alexius and Holmlund (2008) and Ravn and Simonelli (2008).
Our results indicate that unemployment in the labour market adjusts more quickly in Mexico than in Sweden, where Alexius and Holmlund (2008) estimated that a monetary policy shock had its maximum effect on unemployment after nine quarters. In a study evaluating the impact of a monetary policy shock on unemployment in the United States economy, Ravn and Simonelli (2008) found that half the peak effect of such a shock on unemployment had disappeared after 10 quarters and none remained after 10 years.

Hence, the effect of an exogenous tightening of monetary policy on unemployment is less persistent in Mexico than in Sweden and somewhat similar to the effect in the United States economy. The speed of the adjustment can be put down to the existence of a large informal sector and of a number of schemes that have added some employment flexibility despite heavy regulation in the Mexican formal labour market. Labour regulation and labour unions, on the other hand, might explain the low elasticity of employment in the presence of policy shocks. Our results are consistent with previous findings in Latin America. ${ }^{21}$ Unlike those studies, however, this one contends that the existence of a large informal sector and a growing service sector could explain the speed of adjustment found.

${ }^{21}$ See, for example, Loboguerrero and Panizza (2007) and GonzálezAnaya (2002).

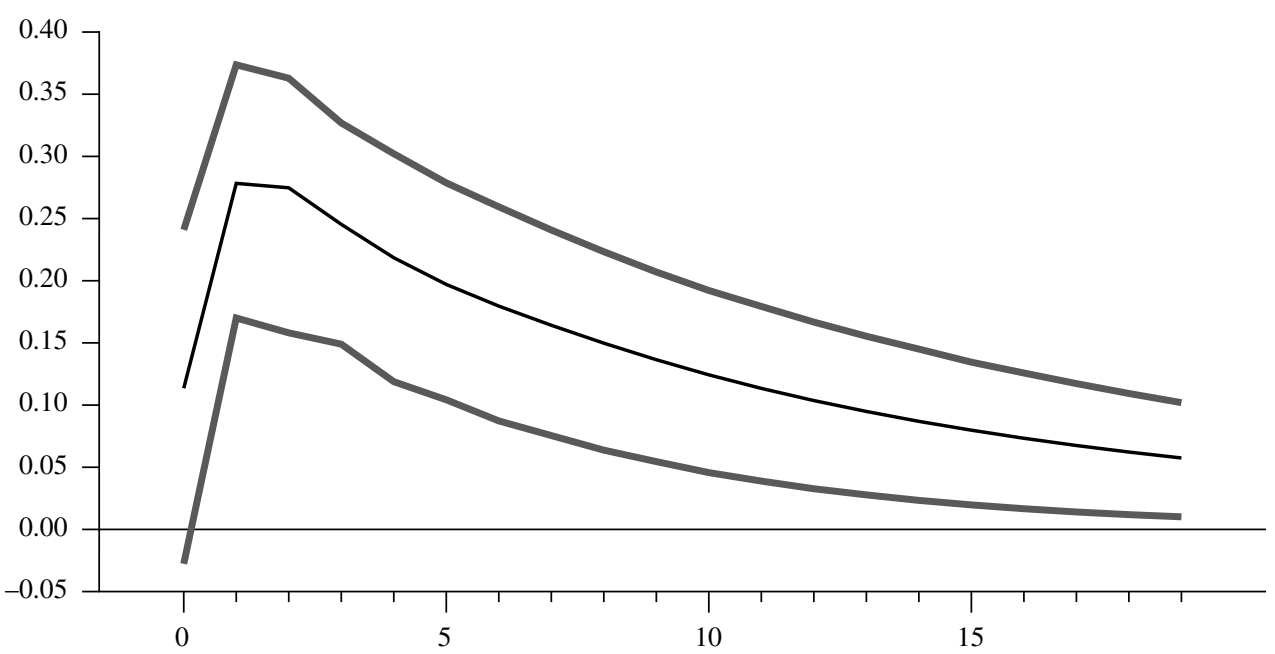

Source: authors' estimates.

Note: Response to a temporary one standard deviation shock in monetary policy. Confidence bands computed by Monte Carlo integration. Following Sims and Zha (1999), we compute percentile bands. 
Figure 2.B shows that a contractionary monetary shock has a negative effect on excess domestic demand. The effect peaks after the first quarter, as compared to the second quarter in the case of unemployment. Half of the peak effect has disappeared by the end of the seventh quarter. These results are statistically significant and different from zero. Much as in the case of unemployment, the estimated impulse response of excess domestic demand reverts back to zero after six years. This result indicates that output falls when monetary policy is restrictive, which is logical since real interest rates affect the cost of capital and thus consumption and investment.

In short, the results indicate that an exogenous tightening of monetary policy will increase unemployment while driving output below its potential level.

\section{Variance decomposition}

Next, we examine the forecast error variance. The forecast error variance decomposition tells us the proportion of the movement in a sequence that is due to its own shocks as opposed to shocks to the other variables. Table 2 reports the forecast error variance decomposition at the 1, 10, 20 and 30 quarter horizons. We are interested in ascertaining what share of unemployment fluctuations is due to monetary policy shocks and to domestic demand shocks (first row). The results indicate that monetary policy shocks account for $1 \%$ to $26 \%$ of fluctuations in unemployment, depending on the time horizon. Excess domestic demand shocks account for about $5 \%$ in the short run, while the share falls to $4 \%$ over a

FIGURE 2.B

Response of the output gap to a monetary policy shock

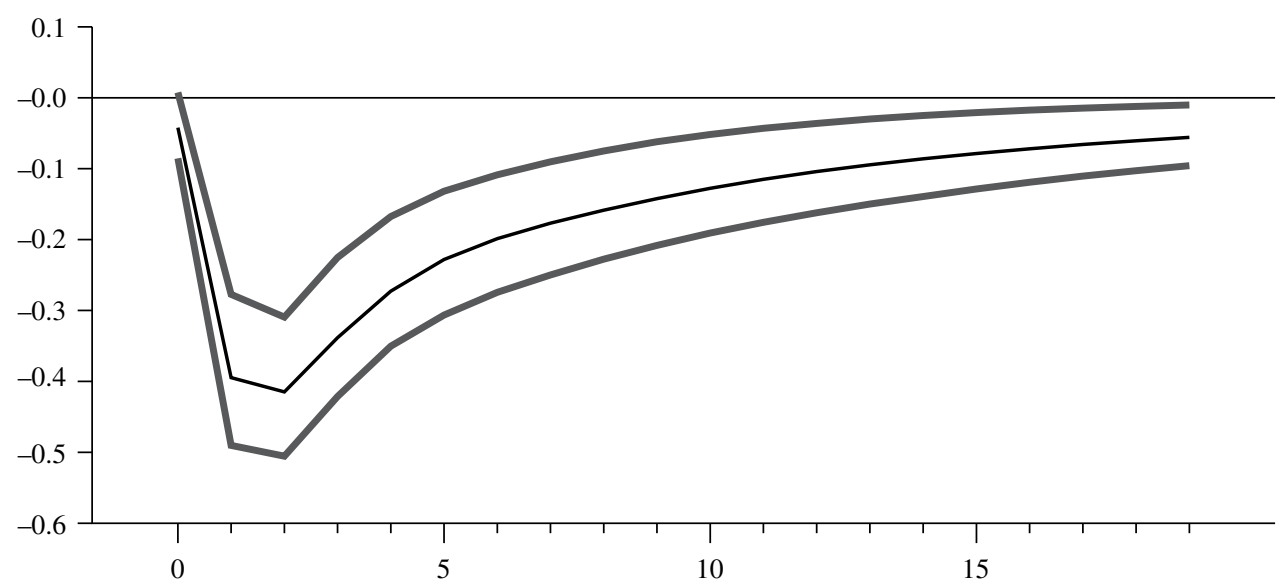

Source: authors' estimates.

Note: Response to a temporary one standard deviation shock in monetary policy. Confidence bands computed by Monte Carlo integration. Following Sims and Zha (1999), we compute percentile bands.

TABLE 2

Variance decomposition

\begin{tabular}{|c|c|c|c|c|c|c|c|c|c|c|c|c|}
\hline \multirow[b]{3}{*}{$\underset{\sim}{\operatorname{Ln}}(u)$} & \multicolumn{4}{|c|}{$\operatorname{Ln}(u)$} & \multicolumn{4}{|c|}{$\tilde{y}$} & \multicolumn{4}{|c|}{$m c i$} \\
\hline & 1 & 10 & 20 & 30 & 1 & 10 & 20 & 30 & 1 & 10 & 20 & 30 \\
\hline & 93.35 & 71.71 & 69.71 & 69.50 & 5.47 & 4.28 & 4.40 & 4.42 & 1.17 & 23.99 & 25.80 & 26.07 \\
\hline$\tilde{y}$ & 0.00 & 9.07 & 11.17 & 11.40 & 100 & 59.34 & 56.08 & 55.73 & 0.00 & 31.57 & 32.71 & 32.85 \\
\hline$m c i$ & 0.00 & 5.02 & 6.92 & 6.88 & 0.72 & 4.94 & 5.04 & 5.04 & 99.27 & 90.02 & 88.26 & 88.06 \\
\hline
\end{tabular}

Source: authors' estimates.

Note: The figures in the second row are horizons (i.e. quarters); all other figures are estimates rounded to two decimal places, so rounding errors may sometimes prevent perfect percentage decomposition.

mci: Monetary Conditions Index.

Ln: natural logarithm.

$\tilde{y}$ : output gap. 
longer horizon. We can observe that, in the short run, unemployment is explained by its own innovation to the extent of about $93 \%$, a share that falls to $69 \%$ over a longer horizon.

\section{Robustness}

Given that the SVAR is estimated on a number of specific assumptions, we investigated the robustness of our results to different sets of assumptions. We estimated four additional models in addition to our baseline model. Model 2, for example, includes as a measure of monetary policy an MCI with derivations of relative weights for interest rates and exchange rates using a trade share approach by estimating an equation for the ratio of long-run exports to GDP. Model 3 is a SVAR model with three lags. This is because, according to the AIC and BIC criteria, there are arguments in favour of two or three lags. In our baseline model we settled for the more parsimonious model specification, i.e. two lags.

In model 4 we drop the assumption that unemployment is not affected by output and let the coefficient be determined by the model, assuming instead that monetary policy does not respond contemporaneously to excess demand ( $\alpha_{12}=0$ ). We maintain the assumption that monetary shocks do not affect excess demand contemporaneously ( $\left.\alpha_{21}=0\right)$ and that unemployment does not affect monetary policy contemporaneously $\left(\alpha_{13}\right.$ $=0$ ). Models 1 to 4 are estimated using the alternative unemployment rate. Model 5, on the other hand, is the baseline model using the official rate of open unemployment.

Figure 3 shows the impulse response function of unemployment to monetary policy shocks for all five models. Except for model 5, the results are quite robust, with the effects peaking after two quarters. The magnitude of the maximum effect varies between 0.26 and 0.50 percentage points when the response is calculated for a monetary policy shock of one standard deviation. As already noted, coefficients estimated using the official unemployment rate are not consistent with economic theory.

Another interesting feature of this comparative analysis is that, five years after the initial shock, unemployment is between 0.004 and 0.12 percentage point higher that it would have been without the shock. Figure 3 also indicates that when we drop the assumption that Mexico's labour market is rigid, the effect of monetary policy on unemployment is even higher (model 4). The higher estimated persistence can also be attributed to the restriction we imposed of monetary policy not responding contemporaneously to the economy. The model with the lowest estimated persistence is the one we assume to have three lags (model 3).

FIGURE 3

\section{Impulse response functions of the five models}

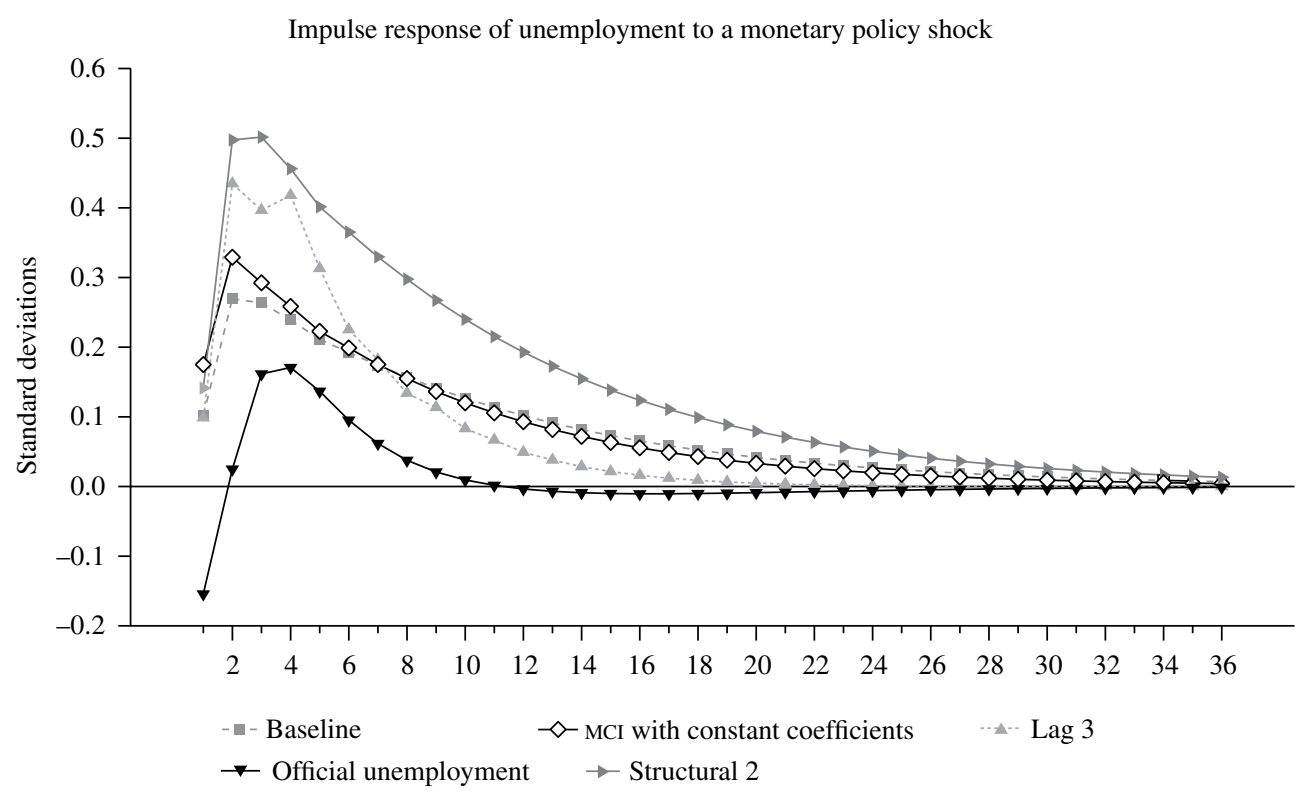

Source: authors' estimates.

Notes: Model 1 = baseline; model $2=$ MCI with constant coefficients; model $3=$ lag 3 ; model $4=$ structural $2 ;$ model $5=$ official unemployment . 
Table 3 reports the forecast error variance decomposition of all five different models at a 1, 10, 20 and 30 quarter horizon. As we may observe, the share of monetary policy shocks in the variance decomposition of unemployment is quite robust at the 10,20 and 30 quarter horizon for models 1 to 4 . The results indicate that monetary policy shocks account for $21 \%$ at the longer horizon in a model with three lags, as compared to $26 \%$ in our baseline model.

Model 5, the one based on the official rate of unemployment, deserves special attention. Our results suggest that an exogenous tightening of monetary policy (shock) of one percentage point would induce a 0.15 percentage point drop in unemployment contemporaneously, and that the effect would then peak after four quarters. The estimated impulse response returns to zero after two and a half years. The variance decomposition analysis indicates that official unemployment rates are exogenous with respect to monetary policy shocks. At this point we do not have a clear explanation for this result, and can only suggest further exploration.

Variance decomposition for the different models

\begin{tabular}{|c|c|c|c|c|c|c|c|c|c|c|c|c|}
\hline & \multicolumn{4}{|c|}{$\operatorname{Ln}(u)$} & \multicolumn{4}{|c|}{$\tilde{y}$} & \multicolumn{4}{|c|}{$m c i$} \\
\hline & 1 & 10 & 20 & 30 & 1 & 10 & 20 & 30 & 1 & 10 & 20 & 30 \\
\hline Model 1 & 93.35 & 71.71 & 69.71 & 69.50 & 5.47 & 4.28 & 4.40 & 4.42 & 1.17 & 23.99 & 25.80 & 26.07 \\
\hline Model 2 & 90.45 & 67.35 & 65.63 & 65.05 & 5.88 & 6.10 & 6.92 & 6.95 & 3.65 & 26.03 & 27.43 & 27.54 \\
\hline Model 3 & 97.87 & 74.45 & 74.55 & 74.55 & 1.21 & 3.61 & 3.99 & 3.99 & 0.95 & 21.93 & 21.45 & 21.44 \\
\hline Model 4 & 38.88 & 28.82 & 27.58 & 27.45 & 60.33 & 48.60 & 48.08 & 48.03 & 0.77 & 22.57 & 24.32 & 24.50 \\
\hline Model 5 & 88.61 & 92.14 & 92.51 & 92.51 & 9.28 & 5.54 & 5.31 & 5.30 & 2.10 & 2.29 & 2.17 & 2.17 \\
\hline
\end{tabular}

Source: authors' estimates.

Note: The figures in the second row are horizons (i.e. quarters); all other figures are estimates rounded to two decimal places, so rounding errors may sometimes prevent perfect percentage decomposition.

mci: Monetary Conditions Index.

Ln: natural logarithm.

$\tilde{y}$ : output gap.

\section{VII}

\section{Conclusions}

We have estimated the impact of macroeconomic stabilization policies on Mexican unemployment rates. The analysis has been carried out for two series of unemployment rates (the official rate and an alternative rate estimated following the methodology used by the CPS of the United States Bureau of Labor Statistics) and for different model specifications.

When official unemployment rates are used, the impulse response function indicates that monetary policy shocks induce an initial drop of about 0.15 percentage points in unemployment. This quickly increases to 0.18 percentage points by the fourth quarter. However, unemployment then returns to its initial level by the tenth quarter; that is, official unemployment rates suggest that the Mexican labour market is very fluid.

When the alternative unemployment rate is used, our results indicate that monetary policy is non-neutral in the short and medium terms. We tested the robustness of our findings under different sets of assumptions. We conclude that our results do not depend on a particular assumption. For example, we find the same qualitative result when we assume a rigid labour market as when we assume a flexible one. The impulse response functions suggest that the impact of a monetary policy shock on unemployment falls by between 0.26 and 0.50 percentage points under different sets of assumptions. Another important result is 
that five years on from the initial shock, unemployment is between 0.004 and 0.12 percentage points higher than it would have been without the shock. We did not find evidence for a long-term impact of monetary policy on unemployment in any case.

Variance decomposition analysis complements the impulse response function findings. While the models based on our alternative measure of unemployment suggest that monetary policy can explain up to $27 \%$ of overall variance, the model based on the official unemployment rate indicates that monetary policy can only explain up to $2.2 \%$ of total variations in unemployment. Obviously, these results represent a puzzle that needs further investigation.
Our estimates of the elasticity of unemployment to monetary shocks suggest that their effect is rather small. However, adjustment to such shocks is faster than in European countries, for example. The low impact of monetary policy can be explained by the existence of some institutional rigidity; namely, intrusive labour regulation and labour unions. These rigidities impede a fuller adjustment to policy shocks. However, there are other elements within the labour market that allow a relatively quick adjustment to such shocks to take place. Among these elements, we consider the existence of a large informal sector and a growing service sector where much labour legislation goes unenforced.

(Original: English)

APPENDIX

TABLE A.1

svar estimates

(Model with lagged inflation, $p$-values in parentheses)

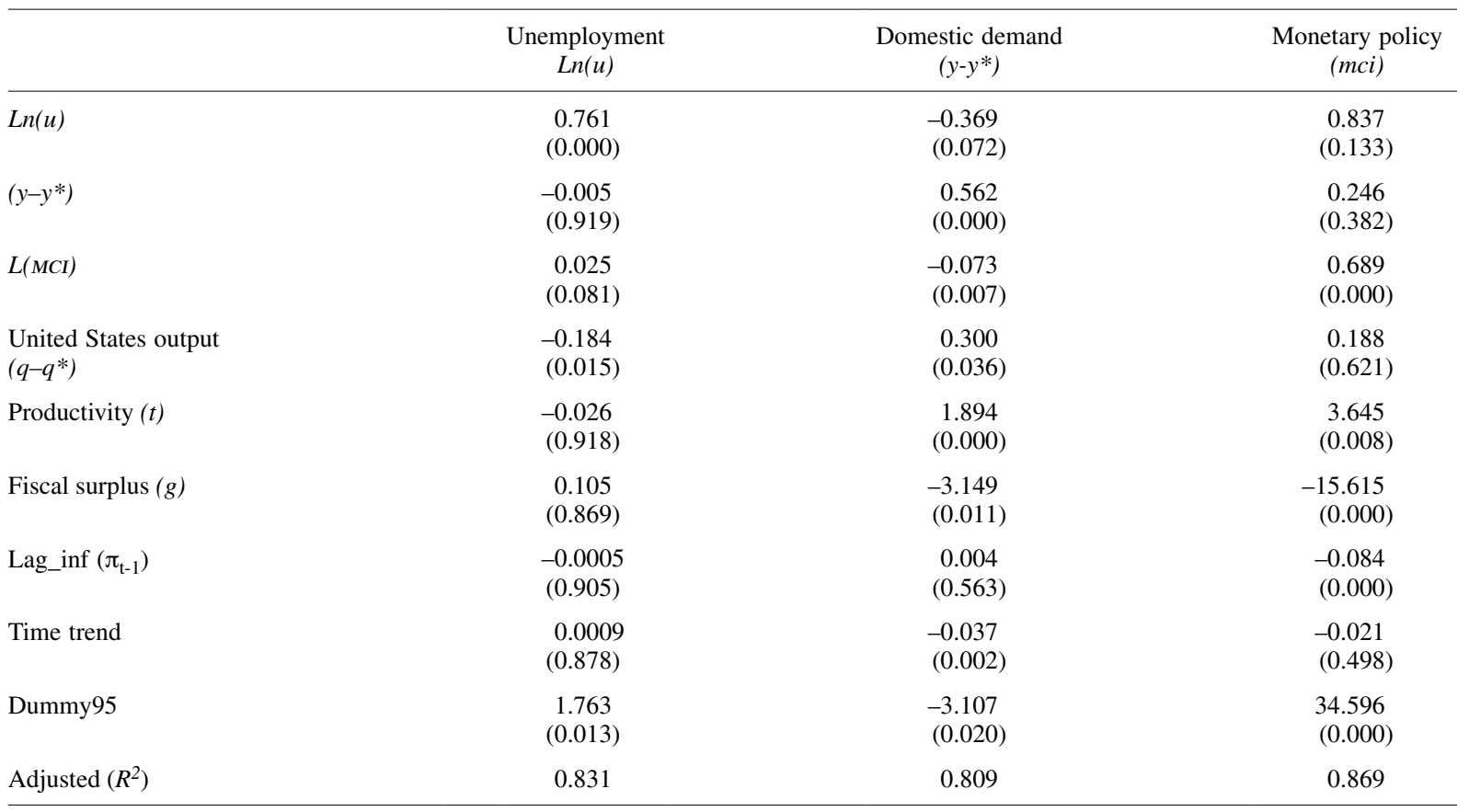

Log likelihood -331.18

Portmanteau (12) 107.1656 (0.1411)

Source: authors' estimates.

Note: The table contains the sum of the coefficients on the two lags of each variable. Wald test for joint significance of both lags of each variable. The portmanteau joint test for white noise residuals is shown.

mci: Monetary Conditions Index. 
TABLE A.2

The endogenous two-break Lagrange multiplier unit root test

Official unemployment. Model C: $K=1, T_{\mathrm{B}_{1}}=1995: 1, T_{\mathrm{B}_{2}}=1999: 3, \mathrm{~N}=72, \lambda_{1}, \cong 0.4, \lambda_{2}, \cong 0.7$

Critical values $5 \%(-5.67) t_{\varnothing}=2.769$

\begin{tabular}{lllcccc}
\hline Parameter & $\mu$ & $d_{1}$ & $d_{t_{1}}$ & $d_{2}$ & $d_{t_{2}}$ & \multicolumn{1}{c}{$\phi$} \\
\hline Estimator & -0.294 & 1.515 & 0.058 & 0.364 & 0.233 & -0.217 \\
T-statistics & $-2.349^{*}$ & $5.030^{*}$ & 0.392 & 1.206 & $2.272^{*}$ & -2.769 \\
\hline
\end{tabular}

Alternative unemployment. Model C: $K=1, T_{\mathrm{B}_{1}}=1995: 1, T_{\mathrm{B}_{2}}=1999: 3, \mathrm{~N}=72, \lambda_{1} \cong 0.4, t_{\varnothing},=-5.452$

Critical values $5 \%(-5.67) t_{0}=-5.452$

\begin{tabular}{lllllll}
\hline Parameter & \multicolumn{1}{c}{$d_{1}$} & \multicolumn{1}{c}{$d_{t_{1}}$} & $d_{2}$ & $d_{t_{2}}$ & \multicolumn{1}{c}{$\phi$} \\
\hline Estimator & -0.574 & 1.874 & 0.383 & 0.487 & 0.808 & -0.6412 \\
T-statistics & $-3.583^{*}$ & $3.062^{*}$ & $1.622^{* *}$ & 0.797 & $3.761^{*}$ & -5.452 \\
\hline
\end{tabular}

Source: authors' estimates.

Note: $*$ and $* *$ denote significance at $5 \%$ and $10 \%$, respectively.

Null: $y_{t}=\mu_{0}+d_{1} B_{1 t}+\mathrm{d}_{t_{1}} D_{1 t}+d_{2} B_{2 t}+d_{\mathrm{t}_{2}} D_{2 t}+y_{t-1}+v_{1 t}$

Alternative: $y_{t}=\mu_{1}+\gamma t+d_{1} D_{1 t}+d_{t_{1}} D T_{1 t}+d_{2} D_{2 t}+d_{t_{2}} D T_{2 t}+v_{2 t}$

where $D_{j t}=1$ for $t \geq T_{B j}+1, j=1,2$ and 0 otherwise; $D T_{j t}=t-T_{B j}$ for $t \geq T_{B j}+1, j=1,2$ and 0 otherwise; $B_{j t}=1$ for $t \geq T_{B j}+1, j=1,2$ and 0 otherwise and $T_{B j}$ denotes time period when a break occurs.

\section{Bibliography}

Andersson, M., H. Dillén and P. Sellin (2006), "Monetary policy signaling and movements in the Swedish term structure of interest rates", Journal of Monetary Economics, vol. 53, No. 8, Amsterdam, Elsevier.

Berger, H., J. de Haan and J-E. Sturm (2011), "Does money matter in the ЕСB strategy? New evidence based on ЕСв communication", International Journal of Economics and Finance, vol. 16, No. 1, John Wiley \& Sons.

Blinder, A. and others (2008), "Central Bank communication and monetary policy: a survey of theory and policy", Journal of Economic Literature, vol. 46, No. 4, Nashville, Tennessee, American Economic Association.

Brand, C., D. Buncic and J. Turunen (2010), "The impact of ECB monetary policy decisions and communication on the yield curve", Journal of the European Economic Association, vol. 8, No. 6, Cambridge, Massachusetts, The MIT Press.

Connolly, E. and M. Kohler (2004), "News and interest rate expectations: a study of six central banks", rba Research Discussion Paper, 04-10, Sydney, Reserve Bank of Australia.

Cook, T. and T. Hahn (1989), "The effect of changes in the federal funds rate target on market interest rates in the 1970s", Journal of Monetary Economics, vol. 24, No. 3, Amsterdam, Elsevier.

Costa Filho, A.E. and F. Rocha (2010), "Como o mercado de juros futuro reage a comunicação do banco central?", Economia aplicada, vol. 14, No. 3.

(2009), "Comunicação e política monetária no el Brasil", Revista brasileira de economia, vol. 63, No. 4, Rio de Janeiro, Getulio Vargas Foundation.

Cragg, J.G. (1983), "More efficient estimation in the presence of heteroscedasticity of unknown form", Econometrica, vol. 51, No. 3, New York, Econometric Society.

De Mendonça, H.F. and J. Simão-Filho (2007), "Economic transparency and effectiveness of monetary policy", Journal of Economic Studies, vol. 34, No. 6, Emerald Group Publishing.
Ehrmann, M. and M. Fratzscher (2009), "Explaining monetary policy decisions in press conferences", International Journal of Central Banking, vol. 5, No. 2, San Francisco.

(2007a), "The timing of central bank communication", European Journal of Political Economy, vol. 23, No. 1, Amsterdam, Elsevier.

(2007b), "Communication by Central Bank Committee members: different strategies, same effectiveness", Journal of Money, Credit and Banking, vol. 39, No. 2-3, Blackwell Publishing.

Evans, C.L. and D.A. Marshall (1998), "Monetary policy and the term structure of nominal interest rates: evidence and theory", Carnegie-Rochester Conference Series on Public Policy, vol. 49, No. 1, Amsterdam, Elsevier.

Ewing, B.T. (2003), "The response of the default risk premium to macroeconomic shocks", The Quarterly Review of Economics and Finance, vol. 43, No. 2, Amsterdam, Elsevier.

Fuhrer, J.C. (1996), "Monetary policy shifts and long term interest rates", Quarterly Journal of Economics, vol. 111, No. 4, Cambridge, Massachusetts, The MIT Press.

Fuhrer, J.C. and G.R. Moore (1995a), "Inflation persistence", Quarterly Journal of Economics, vol. 110, No. 1, Cambridge, Massachusetts, The MIT Press.

(1995b), "Monetary policy trade-offs and the correlation between nominal interest rates and real output", The American Economic Review, vol. 85, No. 1, Nashville, Tennessee, American Economic Association.

Fujiwara, I. (2005), "Is the Central Bank's publication of economic forecasts influential?", Economics Letters, vol. 89, No. 3, Amsterdam, Elsevier.

Geraats, P. (2002), "Central Bank transparency", The Economic Journal, vol. 112, No. 483, Wiley.

Haldane, A.G. and V. Read (2000), "Monetary policy surprises and the yield curve", Bank of England Working Paper, No. 106, London, Bank of England. 
Hansen, L.P. (1982), "Large sample properties of generalized method of moments estimators", Econometrica, vol. 50, No. 4, New York, Econometric Society.

Hayo, B., A. Kutan and M. Neuenkirch (2010), "The impact of U.S. central bank communication on European and pacific equity markets", Economics Letters, vol. 108, No. 2, Amsterdam, Elsevier.

Hayo, B. and M. Neuenkirch (2010), "Do Federal Reserve communications help predict federal funds target rate decisions?", Journal of Macroeconomics, vol. 32, No. 4, Amsterdam, Elsevier.

Jansen, D. and J. de Haan (2005), "Talking heads: the effects of ECB statements on the euro-dollar exchange rate", Journal of International Money and Finance, vol. 24, No. 2, Amsterdam, Elsevier.

Johnston, J. (1984), Econometric Methods, Singapur, McGraw-Hill.

Kohn, D.L. and B. Sack (2004), "Central bank talk: does it matter and why?", Macroeconomics, Monetary Policy, and Financial Stability, Ottawa, Bank of Canada.

Koop, G., M.H. Pesaran and S.M. Potter (1996), "Impulse response analysis in non-linear multivariate models", Journal of Econometrics, vol. 74, No. 1, Amsterdam, Elsevier.

Lima, A. and J. Issler (2003), "A hipótese das expectativas na estrutura a termo de juros no el Brasil: uma aplicação de modelos de valor presente", Revista brasileira de economia, vol. 57, No. 4, Rio de Janeiro, Getulio Vargas Foundation.

Lutkenpohl, H. (1991), Introduction to Multiple Time Series Analysis, Berlin, Springer.

Mishkin, F.S. and M.A. Savastano (2001), "Monetary policy strategies for Latin America", Journal of Development Economics, vol. 66, No. 2, Amsterdam, Elsevier.

Montes, G.C. and J.C.A. Bastos (2011), "Metas de inflação e estrutura a termo das taxas de juros no el Brasil", Economia aplicada, vol. 15, No. 3, São Paulo.

Musard-Gies, M. (2006), "Do ECB's statements steer short-term and long-term interest rates in the Euro-Zone?", The Manchester School, vol. 74 (supplement), Wiley.

Newey, W.K. and K.D. West (1987), "A simple, positive semidefinite, heteroskedasticity and autocorrelation consistent covariance matrix", Econometrica, vol. 55, No. 3, New York, Econometric Society.
Pesaran, M.H. and Y. Shin (1998), "Generalized impulse response analysis in linear multivariate models", Economics Letters, vol. 58, No. 1, Amsterdam, Elsevier.

Ranaldo, A. and E. Rossi (2010), "The reaction of asset markets to Swiss National Bank communication", Journal of International Money and Finance, vol. 29, No. 3, Amsterdam, Elsevier.

Reeves, R. and M. Sawicki (2007), "Do financial markets react to Bank of England communication?", European Journal of Political Economy, vol. 23, No. 1, Amsterdam, Elsevier.

Roley, V. and G. Sellon (1995), "Monetary policy actions and long term interest rates", Economic Review, Kansas, Federal Reserve Bank of Kansas City.

Rosa, C. (2011), "Talking less and moving the market more: evidence from the Есв and the Fed", Scottish Journal of Political Economy, vol. 58, No. 1, Wiley.

Rosa, C. and G. Verga (2007), "On the consistency and effectiveness of Central Bank communication: evidence from the ECB", European Journal of Political Economy, vol. 23, No. 1, Amsterdam, Elsevier.

Rozkrut, M. and others (2007), "Quest for Central Bank communication. Does it pay to be "talkative?", European Journal of Political Economy, vol. 23, No. 1, Amsterdam, Elsevier.

Sims, C. (1980), "Macroeconomics and reality", Econometrica, vol. 48, No. 1, New York, Econometric Society.

Sturm, J.-E. and J. De Haan (2011), "Does central bank communication really lead to better forecasts of policy decisions? New evidence based on a Taylor rule model for the ECB", Review of World Economics, vol. 147, No. 1, Springer.

Tabak, B.M. and A. Tabata (2004), "Surpresas na política monetária e a estrutura a termo da taxa de juros brasileira", Revista de economia aplicada, vol. 8, No. 3 .

Walsh, C.E. (2010), Monetary Theory and Policy, Cambridge, Massachusetts, The mit Press.

Woodford, M. (2003), Interest and Prices: Foundations of a Theory of Monetary Policy, Princeton, Princeton University Press.

Wooldridge, J.M. (2001), "Applications of generalized method of moments estimation", Journal of Economic Perspectives, vol. 15, No. 4, Nashville, Tennessee, American Economic Association. 